\title{
Synthesis, X-ray structure and theoretical investigation of 2-(2'-quinolyl)benzimidazole metal complexes
}

\author{
FERIEL AOUATEF SAHKI ${ }^{\mathrm{a}}$, LYAMINE MESSAADIA ${ }^{\mathrm{b}}$, HOCINE MERAZIG $^{\mathrm{a}}$, \\ AISSA CHIBANI ${ }^{\mathrm{a}}$, ABDELMALEK BOURAIOU $^{\mathrm{a}, *}$ and SOFIANE BOUACIDA ${ }^{\mathrm{a}, \mathrm{c}}$ \\ ${ }^{a}$ Unité de Recherche de Chimie de l'Environnement et Moléculaire Structurale, Université des Frères \\ Mentouri, Constantine 25000, Algérie \\ ${ }^{b}$ Laboratoire Énergétique Appliquée et Matériaux, Université de Jijel, 18000 Jijel, Algérie \\ ${ }^{c}$ Département des sciences de la matière, Université Oum El Bouaghi, 04000, Oum El Bouaghi, Algérie \\ Email: bouraiou.abdelmalek@yahoo.fr
}

MS received 27 June 2016; revised 11 November 2016; accepted 15 November 2016

\begin{abstract}
Synthesis, characterization and DFT analysis of 2-(1 H-benzo[d]imidazol-2-yl)quinoline (BQ) and its cobalt and manganese coordination compounds $\left\{\mathrm{Co}(\mathrm{DMF})(\mathrm{BQ}) \mathrm{Cl}_{2}\right\}$ and $\left\{\mathrm{Mn}(\mathrm{DMF})(\mathrm{BQ}) \mathrm{Cl}_{2}\right\}$ have been described. The ligand, 2-( $1 H$-benzo[ $[d]$ imidazol-2-yl)quinoline (BQ) crystallizes in non-centrosymmetric monoclinic crystal system with cell parameters $\mathrm{a}=12.9280(4) \AA, \mathrm{b}=7.9429(3) \AA, \mathrm{c}=25.8478(9) \AA, \alpha=\gamma=$ $90^{\circ}, \beta=103.005(2)^{\circ} .\left\{\mathrm{Co}(\mathrm{DMF})(\mathrm{BQ}) \mathrm{Cl}_{2}\right\}$ and $\left\{\mathrm{Mn}(\mathrm{DMF})(\mathrm{BQ}) \mathrm{Cl}_{2}\right\}$ crystallized in triclinic space group $\mathrm{P}-1$. The metal(II) environment exhibits trigonal bipyramidal coordination. These complexes show presence of $\mathrm{N}-\mathrm{H} . . . \mathrm{Cl}, \mathrm{C}-\mathrm{H} . . . \mathrm{Cl}$ hydrogen bonds and strong intramolecular $\mathrm{C}-\mathrm{H} . . \mathrm{O}$ interactions. The structure parameters were calculated and they are in good agreement with those observed experimentally. Theoretically calculated frontier molecular orbitals (HOMO-LUMO) of the complexes and their energies indicate intermolecular charge transfer and delocalization of electron density within the molecule.
\end{abstract}

Keywords. Quinoline; benzimidazole; metal complexes; x-ray structure; electronic structure.

\section{Introduction}

Nitrogen-based ligands are extensively studied as complexes with many metal ions such as cobalt and manganese. ${ }^{1,2}$ Coordination complexes based on nitrogen donor chelate ligands and cobalt or manganese ions, having a number of available oxidation states, have attracted great attention because of their potential applications in various fields of human interest such as antitumor, ${ }^{3,4}$ antiviral, ${ }^{5,6}$ antifungal and antibacterial ${ }^{7,8}$ and antioxidant ${ }^{9,10}$ drugs. In addition to the biological importance, diverse catalytic ${ }^{11,12}$ and magnetic properties $^{13,14}$ of such compounds have been explored.

Following our previous works related to the use of benzazole thioether as ligand for new coordination complexes, ${ }^{15,16}$ we report herein new manganese and cobalt complexes containing a polydentate ligand, by combination of quinoline and benzimidazole fragments. In addition, density functional theory calculations were used for determining the electronic structures, geometrical parameters, bonding analysis and reproducing efficiently the experimental structures.

\footnotetext{
*For correspondence
}

\section{Experimental}

\subsection{General considerations}

All chemicals, reagents and solvents were of analytical grade, purchased and used as received. ${ }^{1} \mathrm{H}-\mathrm{NMR}$ and ${ }^{13} \mathrm{C}$ NMR spectra were recorded on Bruker Avance DPX250 spectrometers. The melting point was determined using an Electrothermal IA9100 digital melting point apparatus. UV spectra were recorded on UV/VIS Spectrophotometer Optizen 1220. IR spectra were recorded on Shimadzu FT/IR8201 PC spectrophotometer. Powder X-ray diffraction data were collected on a PANalytical X'Pert PRO X-ray powder diffractometer at room temperature. The $2 \theta$ scan range was $5-60^{\circ}$, with a step size of $0.007^{\circ}$. Microanalysis was performed in Perkin Elmer Elemental Analyzer 2400/II.

\subsection{Synthesis of 2-(1H-benzo[d]imidazol-2-yl) quinoline $(B Q)$}

$10 \mathrm{mmol}$ of phenylene diamine was added to a suspension of quinaldic acid $(10 \mathrm{mmol})$ in $1 \mathrm{~g}$ of polyphosphoric acid. The mixture was heated at $160^{\circ} \mathrm{C}$ for $24 \mathrm{~h}$. After completion of the reaction, water was added and the precipitate that formed was filtered, washed with $\mathrm{H}_{2} \mathrm{O}(2 \times 50 \mathrm{~mL})$. The residue was suspended in $20 \mathrm{~mL}$ of $\mathrm{NaOH}(5 \mathrm{M})$, then filtered to afford the desired product. Yield 92\%; Yellow solid; M.p.: 
85-88 ${ }^{\circ} \mathrm{C} \quad$ (Literature $\left.^{17}: \quad 93-95^{\circ} \mathrm{C}\right)$; UV-Vis $(\mathrm{MeOH}$, $\left.\lambda_{\max } / \mathrm{nm}\right): 286,308,322,336,350$; IR $\left(\mathrm{KBr}, \mathrm{cm}^{-1}\right): 3047$, 1654, 1596, 1566, 1500, 1411, 1319, 1238, 1141, 829, 748; ${ }^{1} \mathrm{H}$ NMR $\left(250.13 \mathrm{MHz}, \mathrm{CDCl}_{3}\right) \delta: 11.21(\mathrm{~s}, 1 \mathrm{H}), 8.64-7.24$ (m, 10H).

\subsection{Preparation of complexes}

2.3a Preparation of $\left\{C o(D M F)(B Q) C l_{2}\right\}$ (1): A solution of $238 \mathrm{mg}$ of $\mathrm{CoCl}_{2}, 6 \mathrm{H}_{2} \mathrm{O}(1 \mathrm{mmol})$ and $245 \mathrm{mg}(1 \mathrm{mmol})$ of 2-(1H-benzo[d]imidazol-2-yl)quinoline (BQ) in $10 \mathrm{~mL}$ of $\mathrm{MeOH}$ was stirred for $18 \mathrm{~h}$ at room temperature. The green precipitate that formed was filtered and dried in vасио. Yield 87\%; M.p.: $205-210^{\circ} \mathrm{C}$; UV-Vis $\left(\mathrm{MeOH}, \lambda_{\max } / \mathrm{nm}\right): 288$, 310, 322, 336; IR $\left(\mathrm{KBr}, \mathrm{cm}^{-1}\right)$ : 3409, 3070, 1593, 1504, 1434, 1326, 1153, 837, 752. Anal. calcd. (\%) for $\mathrm{Co}(\mathrm{BQ}) \mathrm{Cl}_{2}$, $\mathrm{H}_{2} \mathrm{O}\left(\mathrm{C}_{16} \mathrm{H}_{13} \mathrm{Cl}_{2} \mathrm{CoN}_{3} \mathrm{O}\right): \mathrm{C} 48.88, \mathrm{H} 3.33$, N 10.69, found (\%): C 48.93, H 3.28, N 10.81. The crude product was recrystallized in DMF.

2.3b Preparation of $\left\{M n(D M F)(B Q) C l_{2}\right\}$ (2): A solution of $198 \mathrm{mg}$ of $\mathrm{MnCl}_{2}, 4 \mathrm{H}_{2} \mathrm{O}$ (1 mmol) and $245 \mathrm{mg}$ ( $1 \mathrm{mmol})$ of 2-(1H-benzo[d]imidazol-2-yl)quinoline (BQ) in $10 \mathrm{~mL}$ of $\mathrm{MeOH}$ was stirred at room temperature for $18 \mathrm{~h}$. The light yellow precipitate that formed was filtered and dried in vacuo. Yield 78\%; M.p.: $210-213^{\circ} \mathrm{C}$; UV-Vis $\left(\mathrm{MeOH}, \lambda_{\max } / \mathrm{nm}\right): 288,308,322,335 ; \mathrm{IR}\left(\mathrm{KBr}, \mathrm{cm}^{-1}\right)$ : 3436, 3058, 1596, 1504, 1431, 1323, 1149, 837, 756. Anal. calcd. (\%) for $\mathrm{Mn}(\mathrm{BQ})_{2} \mathrm{Cl}_{2}, \mathrm{MeOH}\left(\mathrm{C}_{33} \mathrm{H}_{26} \mathrm{Cl}_{2} \mathrm{MnN}_{6} \mathrm{O}\right)$ : $\mathrm{C}$ 61.12, $\mathrm{H}$ 4.04, $\mathrm{N} 12.96$, found $(\%)$ : $\mathrm{C} 61.40, \mathrm{H}$ 3.91, N 13.57. The crude product was recrystallized in DMF.

\section{$2.4 \quad X$-ray crystallography}

The crystal was coated with Paratone oil and mounted on loops for data collection. X-ray data were collected with a Bruker Apex II CCD area detector diffractometer with a graphite-monochromated Mo-K $\alpha$ radiation source $(0.71073 \AA)$ at $298 \mathrm{~K}$. The reported structure was solved by direct methods with SIR $2002^{18}$ to locate all the non-H atoms which were refined anisotropically with SHELXL97 ${ }^{19}$ using full-matrix least-squares on $\mathrm{F}^{2}$ procedure from within the WinGX ${ }^{20}$ suite of software used to prepare the material for publication. All absorption corrections were performed with the SADABS program. ${ }^{21}$ All the $\mathrm{H}$ atoms were placed in the calculated positions and constrained to ride on their parent atoms, except for $\mathrm{H}$ atoms of water molecule which were located in a difference map and their positions were refined isotropically with $\mathrm{O}-\mathrm{H}$ distance restraints of 0.85 (2) $\AA$ and with $\operatorname{Uiso}(\mathrm{H})=1.2 \mathrm{Ueq}(\mathrm{O})$. Crystal data, structure refinement parameters, selected angles, bond lengths and some intra- and intermolecular interactions, hydrogen bonds for compounds $\mathrm{BQ},\{\mathrm{Co}(\mathrm{DMF})$ (BQ) $\left.\mathrm{Cl}_{2}\right\}$ (1) and $\left\{\mathrm{Mn}(\mathrm{DMF})(\mathrm{BQ}) \mathrm{Cl}_{2}\right\}$ (2) are listed in Tables 1-3.

\subsection{Computational studies}

All the computational studies were carried out using the Gaussian 09 package $^{22}$ and the Gauss-View molecular visualization program. ${ }^{23}$ Density functional theory (DFT) methods using the combination of the Becke exchange functional $^{24}$ and the vp86 non-local correlation functional ${ }^{25}$ combined with the 6-31G $(\mathrm{p}, \mathrm{d})$ basis set were utilized to determine the quantum chemical parameters for the title compounds, such as geometrical parameters, $E_{H O M O}, \mathrm{E}_{L U M O}$, $\Delta \mathrm{E}$ (energy gap) and dipole moment $(\mu)$.

\section{Results and Discussion}

\subsection{Synthesis}

2-(1H-benzo[d]imidazol-2-yl)quinoline (BQ) was synthesized following a literature procedure starting from phenylene diamine and quinaldic acid. ${ }^{26}$ The complexes $\mathbf{1}$ and $\mathbf{2}$ were prepared as description in Scheme 1. The ligand (BQ) was stirred in $\mathrm{MeOH}$ with $\mathrm{MCl}_{2}$ overnight at room temperature. The solid $\mathrm{M}$ (II) complexes was filtered off and dried. These are very stable in the air. The M(II) complexes are soluble in DMF and DMSO but insoluble in water and other organic solvents, such as methanol. To verify the phase purity of the prepared complexes, the PXRD pattern was recorded. The diffractograms indicated that both complexes are pure phases. The obtained complexes were recrystallized in DMF (Scheme 1).

\subsection{Crystal structures}

The ligand (BQ) and the two obtained complexes were recrystallized and suitable crystals of BQ, $\mathbf{1}$ and $\mathbf{2}$ were grown in DMF solution. It should be noted that during the recrystallisation step, the DMF molecule coordinates through $\mathrm{O}$ atoms to the metallic atom in both $\mathrm{M}(\mathrm{II})$ complexes. The X-ray crystallographic analysis confirmed their respective structures and the refined $\mathrm{X}$-ray crystal structures are shown in Figure 1. Crystal data and structural details of the prepared complexes are presented in Table 1.

3.2a Crystal structure of ligand BQ: The ligand 2( $1 H$-benzo[d]imidazol-2-yl)quinoline (BQ) crystallizes in non-centrosymmetric monoclinic crystal system (space group $\mathrm{Cc}$ ). The asymmetric unit contains two cocrystallized water molecules and two ligands, crystallographically independent (molecules A and B). Each molecule consists of a benzimidazole unit connected to quinolyl moiety. The $\mathrm{C}-\mathrm{N}$ bonds lengths values are, $\mathrm{N}(1 \mathrm{~A})-\mathrm{C}(1 \mathrm{~A})(1.379(5) \AA), \mathrm{N}(1 \mathrm{~A})-\mathrm{C}(9 \mathrm{~A})(1.308(4) \AA)$, $\mathrm{N}(2 \mathrm{~A})-\mathrm{C}(10 \mathrm{~A})(1.373(4) \AA), \mathrm{N}(2 \mathrm{~A})-\mathrm{C}(11 \mathrm{~A})(1.371(5) \AA)$, 
Table 1. Crystallographic data and refinement parameters for BQ, complexes $\mathbf{1}$ and $\mathbf{2}$.

\begin{tabular}{|c|c|c|c|}
\hline & BQ & $\left\{\mathrm{Co}(\mathrm{DMF})(\mathrm{BQ}) \mathrm{Cl}_{2}\right\}(\mathbf{1})$ & $\left\{\mathrm{Mn}(\mathrm{DMF})(\mathrm{BQ}) \mathrm{Cl}_{2}\right\}(\mathbf{2})$ \\
\hline Formula & $\mathrm{C}_{16} \mathrm{H}_{11} \mathrm{~N}_{3}, \mathrm{H}_{2} \mathrm{O}$ & $\mathrm{C}_{19} \mathrm{H}_{18} \mathrm{Cl}_{2} \mathrm{Co} \mathrm{N}_{4} \mathrm{O}$ & $\mathrm{C}_{19} \mathrm{H}_{18} \mathrm{Cl}_{2} \mathrm{Mn} \mathrm{N}_{4} \mathrm{O}$ \\
\hline Formula weight & 263.29 & 448.2 & 474.28 \\
\hline Crystal habit, color & Prism, Colorless & Prism, Blue & Prism, Colorless \\
\hline Crystal system & Monoclinic & Triclinic & Triclinic \\
\hline Space group & $\mathrm{Cc}$ & $\mathrm{P}-1$ & $\mathrm{P}-1$ \\
\hline $\mathrm{a}(\AA)$ & $12.9280(4)$ & $8.5673(12)$ & $8.6355(13)$ \\
\hline $\mathrm{b}(\AA)$ & $7.9429(3)$ & $10.7470(17)$ & $10.8411(16)$ \\
\hline c $(\AA)$ & $25.8478(9)$ & $12.1600(16)$ & $12.1779(18)$ \\
\hline$\alpha\left(^{\circ}\right)$ & 90 & $103.071(13)$ & $104.473(7)$ \\
\hline$\beta\left(^{\circ}\right)$ & $103.005(2)$ & $94.461(9)$ & $93.532(7)$ \\
\hline$\gamma\left({ }^{\circ}\right)$ & 90 & $112.97(2)$ & $113.324(6)$ \\
\hline Volume $\left(\AA^{3}\right)$ & 2586.12(16) & $986.8(2)$ & $997.0(3)$ \\
\hline $\mathrm{Z}, \mathrm{Z}^{\prime}$ & 4,8 & 2,2 & 2,2 \\
\hline Density (calculated, $\mathrm{g} \mathrm{cm}^{-3}$ ) & 1.352 & 1.508 & 1.480 \\
\hline Absorption coefficient $\left(\mathrm{mm}^{-1}\right)$ & 0.088 & 1.157 & 0.946 \\
\hline $\mathrm{F}(000)$ & 1104 & 458 & 454 \\
\hline Crystal size $(\mathrm{mm})$ & $0.08 \times 0.13 \times 0.15$ & $0.05 \times 0.10 \times 0.13$ & $0.09 \times 0.14 \times 0.19$ \\
\hline$\theta$ range for data collection $\left(^{\circ}\right)$ & $3.23-30.54$ & $3.42-31.16$ & $3.40-36.23$ \\
\hline Reflections collected & 14330 & 14863 & 36453 \\
\hline Independent reflections & 6562 & 5839 & 9496 \\
\hline $\mathrm{R}_{\text {int }}$ & 0.0352 & 0.0530 & 0.0196 \\
\hline Reflections with $\mathrm{I} \geq 2 \sigma(I)$ & 3757 & 3334 & 7273 \\
\hline Number of parameters & 373 & 246 & 246 \\
\hline Goodness-of-fit on $F^{2}$ & 0.984 & 1.052 & 1.029 \\
\hline Final $\mathrm{R}$ indices $[\mathrm{I} \geq 2 \sigma(I)]$ & 0.0591 & 0.0737 & 0.0348 \\
\hline $\mathrm{R}$ indices [all data] & $R_{1}=0.1145$ & $R_{1}=0.1380, w R_{2}=0.1825$ & $R_{1}=0.0963, w R_{2}=0.1068$ \\
\hline $\begin{array}{l}\text { Largest difference peak and hole } \\
\left(\AA^{-3}\right)\end{array}$ & $\begin{array}{l}w R_{2}=0.1298 \\
0.381,-0.165\end{array}$ & $1.185,-0.88$ & $0.432,-0.248$ \\
\hline CCDC deposition no. & CCDC 1455171 & CCDC 1469612 & CCDC 1455172 \\
\hline
\end{tabular}

Table 2. Distances $(\AA)$ and angles $\left(^{\circ}\right)$ of hydrogen bond for BQ, complexes (1) and (2).

\begin{tabular}{|c|c|c|c|c|c|}
\hline D-H...A & $d(\mathrm{D}-\mathrm{H})$ & $d(\mathrm{H} \ldots \mathrm{A})$ & $d(\mathrm{D}-\mathrm{A})$ & D-H-A & Symmetry \\
\hline \multicolumn{6}{|l|}{ BQ } \\
\hline O1w-H1w...N1a & $0.89(3)$ & $2.24(4)$ & $3.069(4)$ & $156(3)$ & $1 / 2+\mathrm{x}, 1 / 2+\mathrm{y}, \mathrm{z}$ \\
\hline $\mathrm{O} 1 \mathrm{w}-\mathrm{H} 2 \mathrm{w} \ldots \mathrm{N} 3 \mathrm{~b}$ & $0.86(3)$ & $2.02(4)$ & $2.808(4)$ & $151(3)$ & $\mathrm{x}, \mathrm{y}, \mathrm{z}$ \\
\hline $\mathrm{O} 2 \mathrm{w}-\mathrm{H} 3 \mathrm{w} . . \mathrm{O} 1 \mathrm{w}$ & $0.92(3)$ & $2.50(4)$ & $2.948(4)$ & $110(3)$ & $\mathrm{x}, \mathrm{y}, \mathrm{z}$ \\
\hline $\mathrm{O} 2 \mathrm{w}-\mathrm{H} 3 \mathrm{w} . . \mathrm{N} 1 \mathrm{~b}$ & $0.92(3)$ & $2.23(4)$ & $3.035(4)$ & 147(3) & $\mathrm{x}, 1+\mathrm{y}, \mathrm{z}$ \\
\hline $\mathrm{O} 1 \mathrm{w}-\mathrm{H} 4 \mathrm{w} \ldots \mathrm{N} 3 \mathrm{a}$ & $0.88(3)$ & $1.94(4)$ & $2.811(4)$ & $169(4)$ & $\mathrm{x}, \mathrm{y}, \mathrm{z}$ \\
\hline $\mathrm{N} 2 \mathrm{a}-\mathrm{H} 21 \mathrm{a} . . . \mathrm{O} 2 \mathrm{w}$ & 0.86 & 1.9500 & $2.766(4)$ & 159.00 & $-1 / 2+\mathrm{x},-1 / 2+\mathrm{y}, \mathrm{z}$ \\
\hline $\begin{array}{l}\mathrm{N} 2 \mathrm{~b}-\mathrm{H} 21 \mathrm{~b} . . \mathrm{O} 1 \mathrm{w} \\
\left\{\mathrm{Co}(\mathrm{DMF})(\mathrm{BO}) \mathrm{Cl}_{2}\right\}\end{array}$ & 0.86 & 1.9500 & $2.771(4)$ & 159.00 & $\mathrm{x}, \mathrm{y}, \mathrm{z}$ \\
\hline $\mathrm{N} 3-\mathrm{H} 3 \mathrm{n} . . \mathrm{Cl} 2$ & 0.86 & 2.3300 & $3.160(5)$ & 161.00 & $2-x, 1-y,-z$ \\
\hline $\mathrm{C} 12-\mathrm{H} 12 \ldots \mathrm{O} 21$ & 0.93 & 2.5400 & $3.160(5)$ & 123.00 & $\mathrm{x}, \mathrm{y}, \mathrm{z}$ \\
\hline $\begin{array}{l}\mathrm{C} 22-\mathrm{H} 22 \mathrm{a} . . . \mathrm{Cl} 1 \\
\left\{\mathrm{Mn}(\mathrm{DMF})(\mathrm{BQ}) \mathrm{Cl}_{2}\right\}\end{array}$ & 0.96 & 2.7200 & $3.643(9)$ & 161.00 & $2-x, 2-y, 1-z$ \\
\hline N3-H3n...Cl1 & 0.86 & 2.3200 & $3.149(1)$ & 160.00 & $1-x, 1-y,-z$ \\
\hline $\mathrm{C} 12-\mathrm{H} 12 \ldots \mathrm{O} 21$ & 0.93 & 2.5700 & $3.189(2)$ & 124.00 & $\mathrm{x}, \mathrm{y}, \mathrm{z}$ \\
\hline $\mathrm{C} 22-\mathrm{H} 22 \mathrm{a} . . . \mathrm{Cl} 2$ & 0.96 & 2.7200 & $3.633(2)$ & 160.00 & $1-x, 2-y, 1-z$ \\
\hline $\mathrm{C} 23-\mathrm{H} 23 \mathrm{c} \ldots \mathrm{O} 21$ & 0.96 & 2.4400 & $2.772(3)$ & 100.00 & $\mathrm{x}, \mathrm{y}, \mathrm{z}$ \\
\hline
\end{tabular}

$\mathrm{N}(3 \mathrm{~A})-\mathrm{C}(10 \mathrm{~A})(1.308(4) \AA), \mathrm{N}(3 \mathrm{~A})-\mathrm{C}(16 \mathrm{~A}) \quad(1.370$ (5) $\AA$ ) (molecule A), N(1B)-C(1B) (1.379(5) $\AA), N$ (1B)-C(9B) (1.317(4) $), \mathrm{N}(2 \mathrm{~B})-\mathrm{C}(10 \mathrm{~B})(1.347(5) \AA)$,
$\mathrm{N}(2 \mathrm{~B})-\mathrm{C}(11 \mathrm{~B})(1.390(5) \AA), \mathrm{N}(3 \mathrm{~B})-\mathrm{C}(10 \mathrm{~B})(1.317(4) \AA)$, $\mathrm{N}(3 \mathrm{~B})-\mathrm{C}(16 \mathrm{~B})(1.397(5) \AA)$ (molecule B), which indicate partial double bond character (Table 2). Bond 
Table 3. Selected bond lengths $(\AA)$ and angles $\left(^{\circ}\right)$ for ligand BQ, complexes $\mathbf{1}$ and $\mathbf{2}$ with estimated standard deviations; theoretical structure parameters obtained by bvp86/6-31G(d, p) are given in parentheses.

\begin{tabular}{|c|c|c|c|c|}
\hline Bond length/Bond angle & BQ(A) & $\mathrm{BQ}(\mathrm{B})$ & $\left\{\mathrm{Co}(\mathrm{DMF})(\mathrm{BQ}) \mathrm{Cl}_{2}\right\}(\mathbf{1})$ & $\left\{\mathrm{Mn}(\mathrm{DMF})(\mathrm{BQ}) \mathrm{Cl}_{2}\right\}(\mathbf{2})$ \\
\hline $\mathrm{C} 10-\mathrm{N} 2$ & $1.373(4)$ & $\begin{array}{c}1.347(5) \\
(1.336)\end{array}$ & $\begin{array}{c}1.323(6) \\
(1.336)\end{array}$ & $\begin{array}{c}1.3249(13) \\
(1.327)\end{array}$ \\
\hline C10-N3 & $1.308(4)$ & $\begin{array}{c}1.317(4) \\
(1.309)\end{array}$ & $\begin{array}{c}1.354(6) \\
(1.346)\end{array}$ & $\begin{array}{c}1.3488(13) \\
(1.3469)\end{array}$ \\
\hline C16-N3 & $1.370(5)$ & $\begin{array}{c}1.397(5) \\
(1.390)\end{array}$ & $\begin{array}{c}1.375(6) \\
(1.390)\end{array}$ & $\begin{array}{c}1.3808(15) \\
(1.3909)\end{array}$ \\
\hline C9-C10 & $1.477(5)$ & $\begin{array}{c}1.465(5) \\
(1.487)\end{array}$ & $\begin{array}{c}1.467(6) \\
(1.487)\end{array}$ & $\begin{array}{c}1.4685(14) \\
(1.487)\end{array}$ \\
\hline N1-M & & - & $\begin{array}{c}2.275(4) \\
(2.275)\end{array}$ & $\begin{array}{c}2.3781(9) \\
(2.388)\end{array}$ \\
\hline N2-M & & - & $\begin{array}{c}2.042(4) \\
(2.009)\end{array}$ & $\begin{array}{c}2.1772(9) \\
(2.024)\end{array}$ \\
\hline M1-021 & & - & $\begin{array}{c}2.092(4) \\
(2.092)\end{array}$ & $\begin{array}{c}2.1662(9) \\
(2.166)\end{array}$ \\
\hline M-Cl1 & & - & $\begin{array}{l}2.2717(15) \\
(2.271)\end{array}$ & $\begin{array}{c}2.4249(4) \\
(2.424)\end{array}$ \\
\hline $\mathrm{M}-\mathrm{Cl} 2$ & & - & $\begin{array}{c}2.3389(15) \\
(2.338)\end{array}$ & $\begin{array}{c}2.3421(4) \\
(2.342)\end{array}$ \\
\hline N1-C9-C10 & $116.8(3)$ & $\begin{array}{c}116.1(3) \\
(124.2)\end{array}$ & $\begin{array}{c}112.8(4) \\
(113.3)\end{array}$ & $\begin{array}{c}113.99(9) \\
(113.36)\end{array}$ \\
\hline N2-C10-N3 & $112.7(3)$ & $\begin{array}{c}114.0(4) \\
(110.3)\end{array}$ & $\begin{array}{l}113.1(4) \\
(110.34)\end{array}$ & $\begin{array}{c}112.48(9) \\
(110.65)\end{array}$ \\
\hline N1-M1-N2 & & - & $\begin{array}{c}75.94(14) \\
(75.94)\end{array}$ & $\begin{array}{c}73.04(3) \\
(73.70)\end{array}$ \\
\hline N2-M1-Cl1 & & - & $\begin{array}{c}117.09(12) \\
(119.36)\end{array}$ & $\begin{array}{c}117.02(3) \\
(119.42)\end{array}$ \\
\hline Cl1-M1-Cl2 & & - & $\begin{array}{c}118.82(6) \\
(118.81)\end{array}$ & $\begin{array}{c}119.364(17) \\
(119.364)\end{array}$ \\
\hline
\end{tabular}

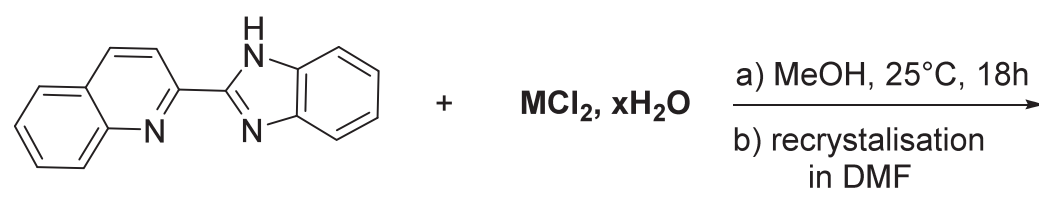

BQ<smiles>CN(C)/C=C/Oc1c(Cl)c(Cl)n2c1[nH]c1ccccc12</smiles>

\section{$\left\{\mathrm{Co}(\mathrm{DMF})(\mathrm{BQ}) \mathrm{Cl}_{2}\right\}$ (1)} $\left\{\mathrm{Mn}(\mathrm{DMF})(\mathrm{BQ}) \mathrm{Cl}_{2}\right\}(2)$

Scheme 1. Synthesis of $\mathbf{1}$ and 2.

angles for $\mathrm{N}(1 \mathrm{~A})-\mathrm{C}(9 \mathrm{~A})-\mathrm{C}(10 \mathrm{~A})$ and for $\mathrm{N}(2 \mathrm{~A})-$ $\mathrm{C}(10 \mathrm{~A})-\mathrm{N}(3 \mathrm{~A})$ are $116.8(3)^{\circ}$ and $112.7(3)^{\circ}$, respectively, and the bond angle $\mathrm{N}(2 \mathrm{~A})-\mathrm{C}(10 \mathrm{~A})-\mathrm{C}(9 \mathrm{~A})$ is 120.9 (3) A (Table 1). Both molecules A and B are almost planar and parallel which form a dihedral angle of $0.93(2)^{\circ}$. The crystal packing can be described as alternating double layers in zigzag manner along the $b$ axis (at $b=0$ and $b=1 / 2$ ) parallel to (010) plane (Figure 2). These layers are connected together with water molecule via O-H...N and $\mathrm{N}-\mathrm{H}$...O hydrogen bonding interactions resulting in the formation of three dimensional network. Hydrogen bond between amine moieties and water molecule form a chain with $D_{1}^{1}(2)$ graph set motif, ${ }^{27}$ when water molecule acts as acceptor as well as donor. Additional hydrogen-bonding parameters are listed in Table 2 . The packing is consolidated by slipped $\pi-\pi$ stacking with centroid to centroid distance of 3.777(2) $\AA$ 

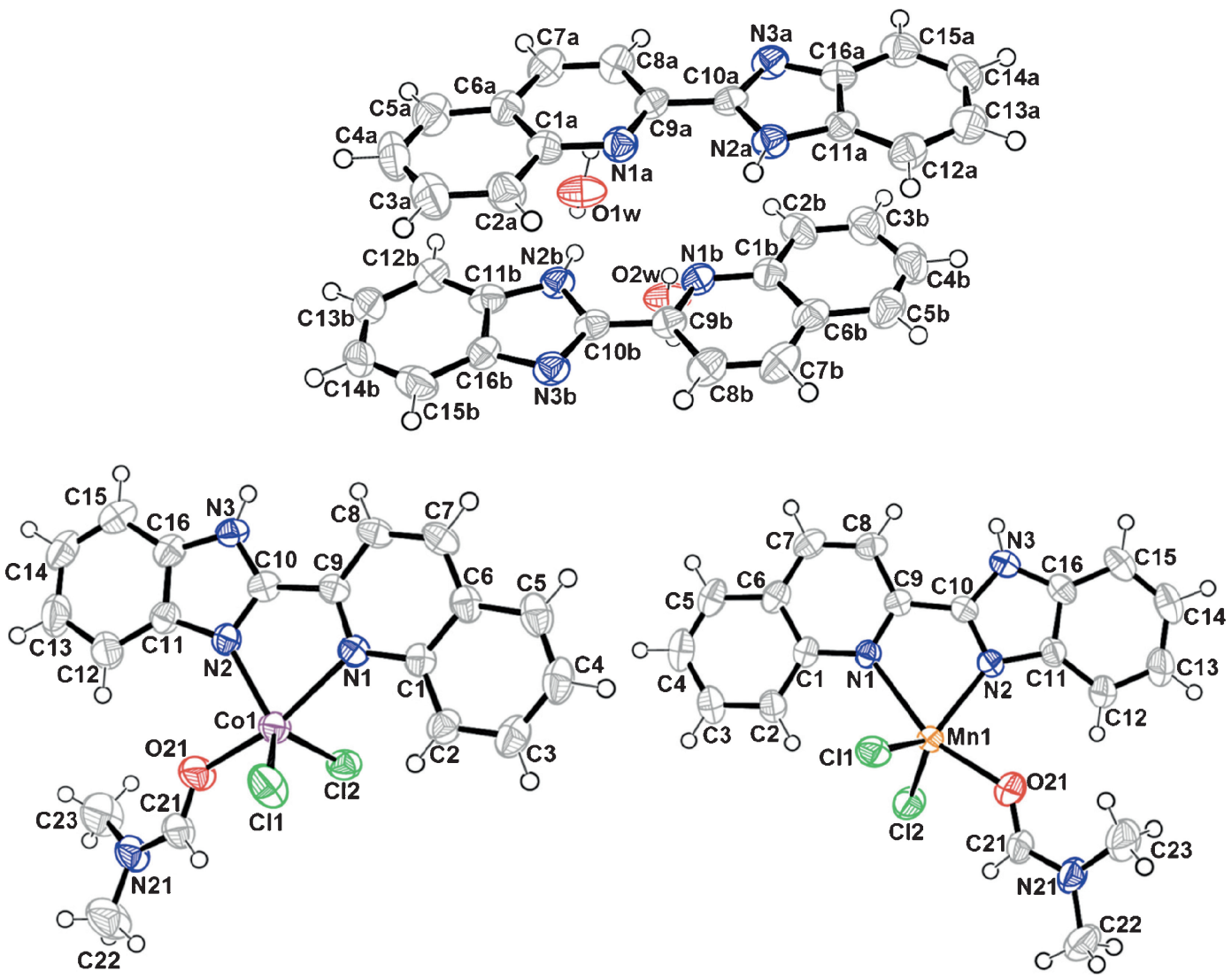

Figure 1. Oak Ridge thermal ellipsoid plots (ORTEP) of the molecular structures of $\mathrm{BQ}$, $\left\{\mathrm{Co}(\mathrm{DMF})(\mathrm{BQ}) \mathrm{Cl}_{2}\right\}(\mathbf{1})$, and $\left\{\mathrm{Mn}(\mathrm{DMF})(\mathrm{BQ}) \mathrm{Cl}_{2}\right\}(2)$ in the crystal and atom numbering scheme adopted (displacement ellipsoids at the $50 \%$ probability level; $\mathrm{H}$ atoms with arbitrary radii).

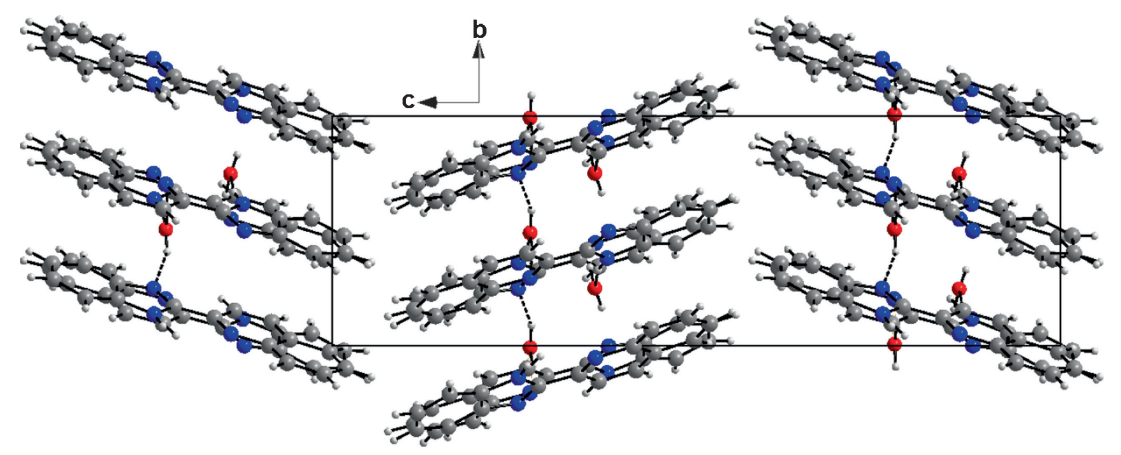

Figure 2. Diagram packing of $B Q$ viewed along the a axis showing layers in zigzag parallel to (010) plane which are connected with water molecule with $\mathrm{N}-\mathrm{H}$...O and $\mathrm{O}-\mathrm{H} . . . \mathrm{N}$ hydrogen bonds.

to $3.878(2) \AA$. All these interactions link the molecule within the layers and also link layers together and reinforce the cohesion of the organic structure.

\section{2b Crystal structure of complexes $\{\mathrm{Co}(\mathrm{DMF})(B Q)$} $\left.C_{2}\right\}$ (1) and $\left\{M n(D M F)(B Q) C l_{2}\right\}$ (2): The compounds 1 and $\mathbf{2}$ crystallized in triclinic space group P-1. Selected bond distances and bond angles for both compounds are listed in Tables 3 and 4. Both complexes are five-coordinated (Figure 1, Table 1). The metal ion is surrounded by two $\mathrm{N}$-donor atoms of the
2-(1H-benzo[d]imidazol-2-yl)quinoline (BQ) ligand, two chloride ions and one coordinated DMF molecule (Figure 1). Each complex contains one organic ligand that contain two rings, N1, C1-C9 (quinoline ring) and $\mathrm{N} 2, \mathrm{~N} 3, \mathrm{C} 10-\mathrm{C} 16$ (benzimidazole ring).

The metal (II) environment exhibits Trigonal bipyramidal coordination. The bond lengths around the metal centers are in the range of 2.042(4)-2.3781(13) $\AA$ $(\mathrm{N}-\mathrm{M}), 2.2717(15)-2.4249(4) \AA \quad(\mathrm{Cl}-\mathrm{M}), 1.237(7)-$ 1.2383(16) (O-M). Bond angles for N1-Co1-Cl1, N1-Mn1-Cl1, Cl1-Co1-O21 and for Cl1-Mn1-O21 
Table 4. Calculated quantum chemical parameters of the BQ and complexes $\mathbf{1}$ and $\mathbf{2}$ calculated at DFT at the bvp86/6-31G (d, p) level.

\begin{tabular}{lccc}
\hline Parameters & $\mathrm{BQ}$ & $\left\{\mathrm{Co}(\mathrm{DMF})(\mathrm{BQ}) \mathrm{Cl}_{2}\right\}(\mathbf{1})$ & $\left\{\mathrm{Mn}(\mathrm{DMF})\left(\mathrm{BQ}^{2} \mathrm{Cl}_{2}\right\}(\mathbf{2})\right.$ \\
\hline Total energy (Hartree) & -780.57620552 & -3332.4023263 & -3100.6407187 \\
$E_{H O M O}(\mathrm{eV})$ & -5.0197 & -4.569 & -4.628 \\
$E_{L U M O}(\mathrm{eV})$ & -2.736 & -3.773 & -3.556 \\
$\Delta \mathrm{E}_{\mathrm{H}-\mathrm{L}}(\mathrm{eV})$ & 2.283 & 0.796 & 1.072 \\
$\mu($ debye $)$ & 4.5409 & 8.6330 & 8.3973 \\
\hline
\end{tabular}

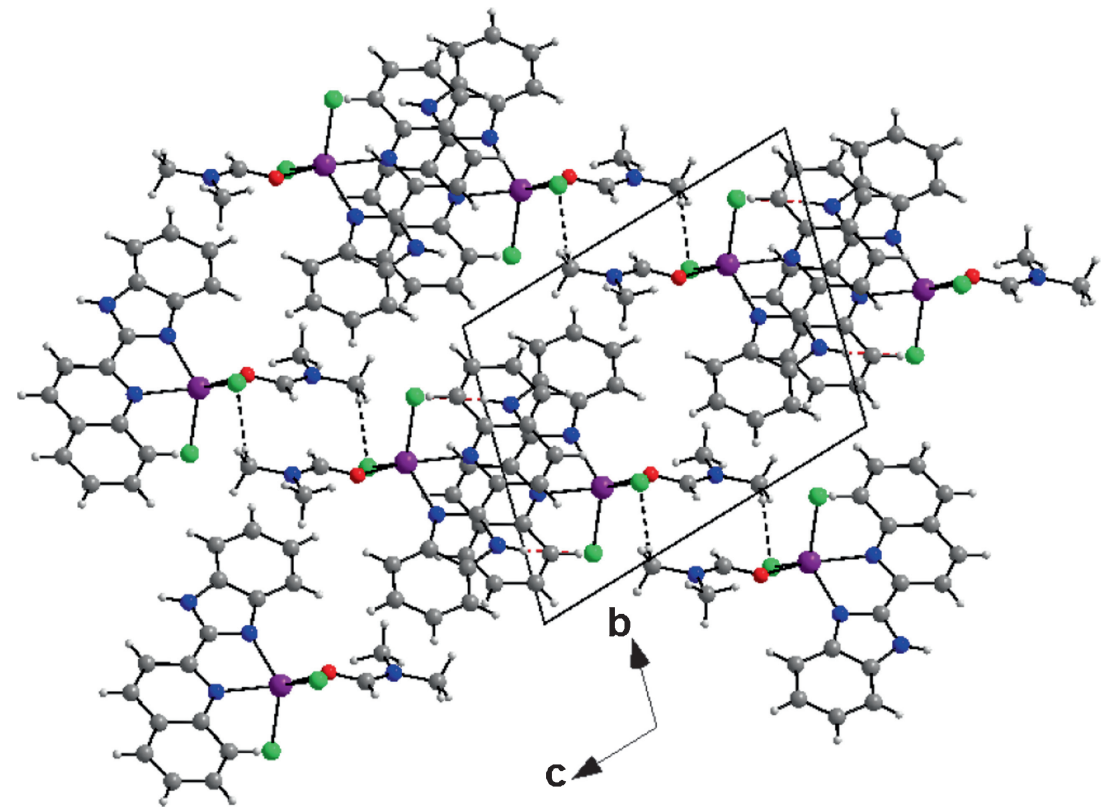

Figure 3. Diagram packing of $\mathbf{1}$ showing layers parallel to (1-10) plane and $\mathrm{C}-\mathrm{H}$... $\mathrm{Cl}$ interactions in black $\left(R_{2}^{2}(12)\right)$.

are $98.46(10)^{\circ}, 88.53(2)^{\circ}, 97.32(16)^{\circ}$ and $90.64(3)^{\circ}$, respectively. Bond lengths and angles are comparable to those reported previously and are in the expected range. ${ }^{28,29}$

The crystal packing for both complexes can be described as alternating layers parallel to (1-10) plane (Figures 3 and 4). In these layers, the arrangement of each molecule induces strong $\pi-\pi$ stacking intermolecular interaction. The shortest centroid-centroid distances are 3.458(3) and 3.465(1) $\AA$ for Co and $\mathrm{Mn}$ complex, respectively. Also these complexes present $\mathrm{N}-\mathrm{H}$. . . Cl and $\mathrm{C}-\mathrm{H}$... Cl hydrogen bonds forming chain and ring, respectively, with $D_{1}^{1}(2)$ and $R_{2}^{2}(12)$ graph set motif. ${ }^{27}$ Strong intramolecular interactions of C$\mathrm{H}$...O are found in the crystal packing. (Figures 3 and 4, Table 2).

\subsection{Computational details}

3.3a Geometrical structure: The optimized structure parameters (bond lengths and angles) for title complexes were calculated using the density functional theory (DFT)/ bvp86/6-31G (p, d) method. The structural parameters such as bond length and bond angles found from the crystal structures are compared with those of optimized geometries. Table 3 summarizes some selected geometrical parameters of the investigated compounds. In general, the obtained results were found to be in good agreement with experimental values, except some bond lengths, such as C9-C10 and N2-M $(\mathrm{M}=\mathrm{Co}, \mathrm{Mn})$. For example, deviations between calculated and experimental N2-M bonds distances are 0.01 Affor $\mathbf{B Q ( A ) , 0 . 0 2 2 ~ \AA ⿱ A 一 f o r ~} \mathbf{B Q}(\mathbf{B})$, $0.020 \AA$ for complex 1 and $0.018 \AA$ for complex 2, respectively. However, for bond angles, we can see that the variations are shorter and longer between the experimental and optimized values due to intermolecular interactions by quinoline with the metal. Moreover, we note that the experimental results belong to the solid state and the theoretical calculations belong to the gas phase.

3.3b Frontier molecular orbitals (HOMO-LUMO) analysis: The optimization of molecular geometry of title compounds in the gas phase was calculated in 


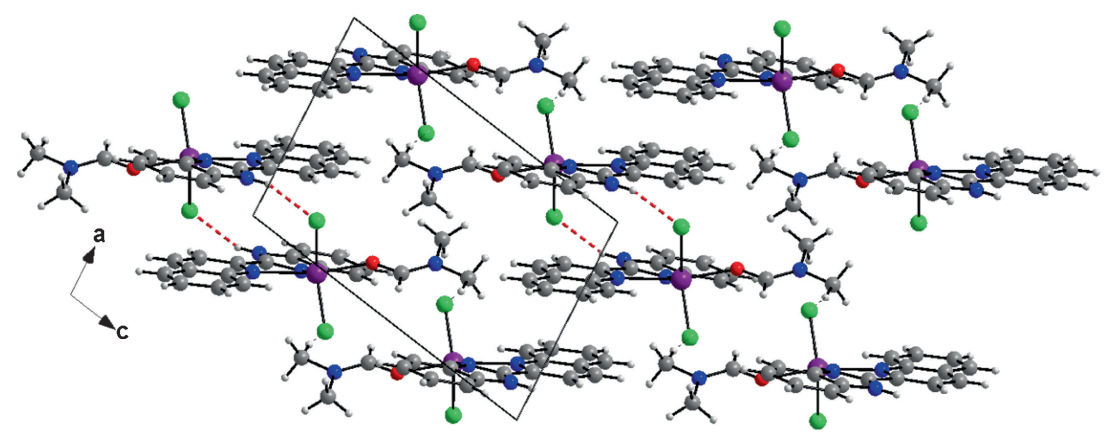

Figure 4. Diagram of packing of $\mathbf{1}$ viewed along a axis showing $\mathrm{N}-\mathrm{H}$... $\mathrm{Cl}$ interactions in red $\left(D_{1}^{1}(2)\right)$.

(a)

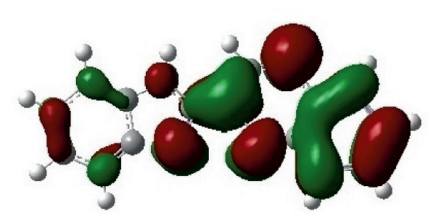

LUMO (-2.736 eV)

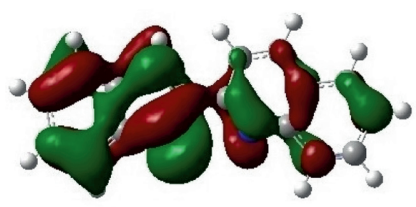

HOMO (-5.0197 eV) (b)

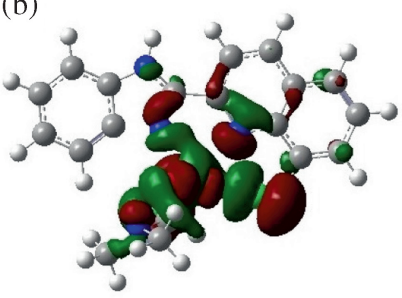

LUMO (-3.773 eV)

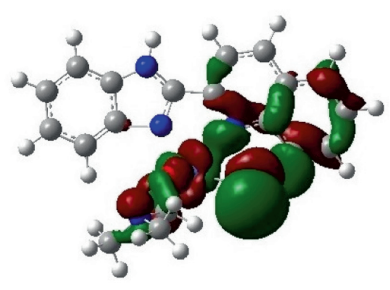

HOMO (-4.569 eV) (c)

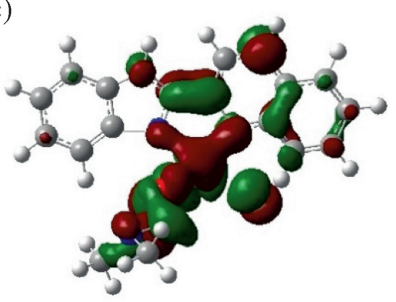

LUMO (-3.556 eV)

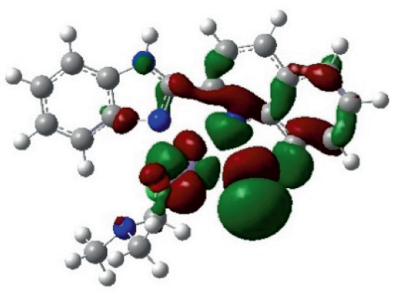

HOMO (-4.628 eV)

Figure 5. Frontier molecular orbitals of compounds (a) ligand BQ, (b) complex $\left\{\mathrm{Co}(\mathrm{DMF})(\mathrm{BQ}) \mathrm{Cl}_{2}\right\}(\mathbf{1})$, and (c) complex $\left\{\mathrm{Mn}(\mathrm{DMF})(\mathrm{BQ}) \mathrm{Cl}_{2}\right\}$ (2).

order to study the stability of the total energy and the energy gap between the frontier molecular orbitals $\left(\Delta \mathrm{E}_{\mathrm{H}-\mathrm{L}}=\mathrm{E}_{\mathrm{HOMO}}-\mathrm{E}_{\mathrm{LUMO}}\right)$ using the density functional theory (DFT) at bvp86/6-31G (d, p) level. The frontier orbital gap helps to characterize the chemical reactivity and kinetic stability of the molecules. A molecule with a small frontier orbital gap is more polarizable and is generally associated with a high chemical reactivity, low kinetic stability and is also called as a soft molecule. ${ }^{30}$ The HOMO represents ability to donate an electron and LUMO represents the ability to accept an electron. Table 4 shows the total energy, $\mathrm{E}_{\mathrm{LuMO}}, \mathrm{E}_{\mathrm{HOMO}}$ and $\Delta \mathrm{E}_{\mathrm{H}-\mathrm{L}}$ energy gap of both complexes $\mathbf{1}, \mathbf{2}$ and Ligand BQ. The calculations indicate that the complex $\mathbf{1}$ has lower value of total energy and energy gap $\left(\Delta \mathrm{E}_{\mathrm{H}-\mathrm{L}}\right)$ than complex 2 . Therefore, complex $\mathbf{1}$ is more reactive than 2 . The $3 \mathrm{D}$ plots of the frontier molecular orbitals HOMO and LUMO for title compounds are illustrated in Figure 5. As can be seen in Figure 5, the HOMO for complexes $\mathbf{1}$ and $\mathbf{2}$ are mainly located over the chlorine $(\mathrm{Cl})$, azote $(\mathrm{N} 1, \mathrm{~N} 21)$, oxygen $(\mathrm{O} 21)$ and cobalt $(\mathrm{Co})$ atoms, with contributions on the quinoline ring $\mathrm{BQ}(\mathrm{B})$. The LUMO is mostly centered in chlorine $(\mathrm{Cl})$, azote $(\mathrm{N} 1, \mathrm{~N} 21, \mathrm{~N} 2, \mathrm{~N} 3)$, oxygen $(\mathrm{O} 21)$ and cobalt (Co) atoms, with slight contribution of quinoline ring $\mathrm{BQ}(\mathrm{B})$. In the case of ligand $\mathrm{BQ}$, the $\mathrm{HOMO}$ is delocalized almost over the whole $\pi$-conjugated system, while the LUMO, and is also delocalized over the whole molecule. The LUMO and HOMO energy gap for the complex 1 equal to $0.796 \mathrm{eV}$, which is lower than that of complex $2(1.072 \mathrm{eV})$ and ligand $\mathrm{BQ}(2.283 \mathrm{eV})$, reflecting intermolecular charge transfer and delocalization of electron density within the molecule. ${ }^{31}$ Therefore, it is clear that the complex $\mathbf{1}$ is more reactive and more polar than complex $\mathbf{2}$ and ligand BQ.

\section{Conclusions}

In summary, this paper describes the synthesis, single crystal X-ray diffraction analysis and DFT studies of 
2-(2'-quinolyl)benzimidazole and Co and Mn complexes. The complexes were synthesized using a simple method. Single crystal X-ray diffraction analysis of the studied complexes reveals a trigonal bipyramidal coordination of the metal(II) environments. These complexes present $\mathrm{N}-\mathrm{H}$. . .Cl, C-H...Cl and $\mathrm{C}-\mathrm{H} . . . \mathrm{O}$ interactions in the crystal packing. The theoretical and experimental bond lengths and angles are in good agreement with each other. Theoretically calculated frontier molecular orbitals (HOMO-LUMO) of both complexes suggest intermolecular charge transfer and delocalization of electron density within the molecule. The accuracy of the results also predicts that the DFT studies performed at bvp86/6-31G (p, d) level is an appropriate quantum chemical method for reproducing efficiently the experimental structures.

\section{Supplementary Information (SI)}

Crystallographic information for all the compounds have been deposited with the Cambridge crystallographic data center, (CCDC) as supplementary publications CCDC 1455171, 1469612 and 1455172. The electronic Supplementary Information is available at www.ias.ac.in/chemsci.

\section{Acknowledgements}

We are grateful to the Ministère de l'Enseignement Supérieur et de la Recherche Scientifique - Algérie (MESRS) for financial support.

\section{References}

1. Hashihayata T, Ito Y and Katsuki T 1996 Enantioselective epoxidation of 2,2-dimethylchromenes using achiral $\mathrm{Mn}$-Salen complex as catalyst in the presence of chiral amine Synlett 1079

2. Soliman S M, Abu Youssef M A M, Albering J and El Faham A 2015 Molecular structure and DFT investigation on new cobalt(II) chloride complex with superbase guanidine type ligand J. Chem. Soc. 1272137

3. Lv J, Liu T, Cai S, Wang X, Liu L and Wang Y 2006 Synthesis, structure and biological activity of cobalt(II) and copper(II) complexes of valine-derived schiff bases J. Inorg. Biochem. 1001888

4. Zhong X, Wei H-L, Liu W-S, Wang D-Q and Wang X 2007 The crystal structures of copper(II), manganese(II), and nickel(II) complexes of a (Z)-2-hydroxyN'-(2-oxoindolin-3- ylidene) benzohydrazide-potential antitumor agents Bioorg. Med. Chem. Lett. 173774

5. Takeuchi T, Böttcher A, Quezada C M, Meade T J and Gray H B 1999 Inhibition of Thermolysin and HumanThrombin by Cobalt(III) Schif Base Complexes Bioorg. Med. Chem. 7815

6. Rogolino D, Carcelli M, Bacchi A, Compari C, Contardi L, Fisicaro E, Gatti A, Sechi M, Stevaert A and Naesens L 2015 A versatile salicyl hydrazonic ligand and its metal complexes as antiviral agents J. Inorg. Biochem. 1509

7. Maghami M, Farzaneh F, Simpson J, Ghiasi M and Azarkish M 2015 Synthesis, crystal structure, antibacterial activity and theoretical studies on a novel mononuclear cobalt(II) complex based on 2,4,6-tris(2-pyridyl)-1,3,5triazine ligand J. Mol. Struct. 109324

8. Kani I, Atlier Ö and Güven K 2016 Mn(II) complexes with bipyridine, phenanthroline and benzoic acid: Biological and catalase-like activity J. Chem. Sci. 128523

9. Dimiza F, Papadopoulos A N, Tangoulis V, Psycharis V, Raptopoulou C P, Kessissoglou D P and Psomas G 2012 Biological evaluation of cobalt(II) complexes with non-steroidal anti-inflammatory drug naproxen J. Inorg. Biochem. 10754

10. Bernard A-S, Giroud C, Ching H Y V, Meunier A, Ambike V, Amatore C, Collignon G M, Lemaître F and Policar C 2012 Evaluation of the anti-oxidant properties of a SOD-mimic Mn-complex in activated macrophages Dalton Trans. 416399

11. Miura K and Katsuki T 1999 Dynamic Control of Ligand Conformation: Asymmetric Epoxidation Using Achiral (Salen)manganese(III) Complex Synlett 783

12. Yamada T, Ikeno T, Sekino H and Sato M 1999 Optically Active Aldiminato Cobalt(II) Complexes as Efficient Catalysts for Enantioselective Cyclopropanation of Styrenes with Diazoacetates Chem. Lett. 28719

13. Alam R, Pal K, Shaw B K, Dolai M, Pal N, Saha S K and Ali M 2016 Synthesis, structure, catalytic and magnetic properties of a pyrazole based five coordinated di-nuclear cobalt(II) complex Polyhedron 10684

14. Yuan J, Wang X, Liu M-J and Kou H-Z 2016 Manganese (III) complexes derived from 1-(2-hydroxybenzamido) -2-((2-hydroxy-3-methoxybenzylidene) amino)ethane: Synthesis, structure and magnetic properties Inorg. Chim. Acta 44969

15. Mezhoud B, Bouchouit M, Said M E, Messaadia L, Belfaitah A, Merazig H, Chibani A, Bouacida S and Bouraiou A 2016 Synthesis, X-ray structure and theoretical study of benzazole thioether and its zinc complex as corrosion inhibitors for steel in acidic medium Res. Chem. Intermed. 427447

16. Bouchouit M, Benzerka S, Bouraiou A, Merazig H, Belfaitah A and Bouacida S 2015 Crystal structure of $\quad\left\{\right.$ bis $\left[\left(1 H\right.\right.$-benzimidazol-2-yl- $\left.\kappa N^{3}\right)$ methyl $]$ sulfane $\}$ dichloridomercury(II) Acta Cryst. E71 m253

17. Mamedov V A, Saifina D F, Gubaidullin A T, Ganieva V R, Kadyrova S F, Rakov D V, Rizvanov I K and Sinyashin O G 2010 Acid-catalyzed rearrangement of 3 -( $\beta$-2-aminostyryl)quinoxalin-2(1H)ones-a new and efficient method for the synthesis of 2-benzimidazol-2ylquinolines Tetrahedron Lett. 516503

18. Burla M C, Caliandro R, Camalli M, Carrozzini B, Cascarano G L, De Caro L, Giacovazzo C, Polidori G and Spagna R 2005 SIR2004: An improved tool for crystal structure determination and refinement J. Appl. Cryst. 38381

19. Sheldrick G M 2008 A short history of SHELX Acta Cryst. A 64112

20. Farrugia L J 2012 WinGX and ORTEP for Windows: An update J. Appl. Cryst. 45849 
21. Sheldrick G M 2002 SADABS (Bruker AXS Inc.: Madison, Wisconsin, USA)

22. Frisch M J, Trucks G W, Schlegel H B, Scuseria G E, Robb M A, Cheeseman J R, Scalmani G, Barone V, Mennucci B, Petersson G A, Nakatsuji H, Caricato M, Li X, Hratchian H P, Izmaylov A F, Bloino J, Zheng G, Sonnenberg J L, Hada M, Ehara M, Toyota K, Fukuda R, Hasegawa J, Ishida M, Nakajima T, Honda Y, Kitao O, Nakai H, Vreven T, Montgomery J A, Peralta Jr J E, Ogliaro F, Bearpark M, Heyd J J, Brothers E, Kudin K N, Staroverov V N, Keith T, Kobayashi R, Normand J, Raghavachari K, Rendell A, Burant J C, Iyengar S S, Tomas i J, Cossi M, Rega N, Millam J M, Klene M, Knox J E, Crossi J B, Bakken V, Adamo C, Jaramillo J, Gomperts R, Stratmann R E, Yazyev O, Austin A J, Cammi R, Pomelli C, Ochterski J W, Martin R L, Morokuma K, Zakrzewski V G, Voth G A, Salvador P, Dannenberg J J, Dapprich S, Daniels A D, Farkas O, Foresman J B, Ortiz J V, Cioslowski J and Fox D J 2009 Gaussian 09, Revision C.01; Gaussian Inc., Wallingford CT

23. Dennington R, Keith T and Millam J 2009 GaussView Version 5.0.9 (Semichem Inc.: Shawnee Mission KS)

24. Becke A D 1988 Density-functional exchange-energy approximation with correct asymptotic behavior Phys. Rev. A 383098
25. Perdew J P 1986 Density-functional approximation for the correlation energy of the inhomogeneous electron gas Phys. Rev. B 338822

26. Hisano T, Ichikawa M and Tsumoto K 1982 Synthesis of Benzoxazoles, Benzothiazoles and Benzimidazoles and Evaluation of Their Antifungal, Insecticidal and Herbicidal Activities Chem. Pharm. Bull. 302996

27. Etter M C, MacDonald J C and Bernstein J 1990 Graphset analysis of hydrogen-bond patterns in organic crystals Acta Cryst. B $\mathbf{4 6} 256$

28. Min J, Zhang Q, Sun W, Cheng Y and Wang L 2011 Neutral copper(I) phosphorescent complexes from their ionic counter parts with 2-(2'-quinolyl)benzimidazole and phosphine mixed ligands Dalton Trans. 40686

29. Chen S Y, Guo Y C, Zhang L F, Feng Y Q, Zhang Y Y and Huaxue J 2013 Syntheses, Crystal Structures and Photoluminescence Properties of Cadmium(II) and Nickel(II) Complexes with 2-(2-Benzimidazolyl) quinoline Chin. J. Struct. Chem. 32643

30. Fleming I 1976 In Frontier Orbitals and Organic Chemical Reactions (New York: John Wiley) pp. 5-27

31. Bouchouit M, Elkouari Y, Messaadia L, Bouraiou A, Arroudj S, Bouacida S, Taboukhat S and Bouchouit K 2016 Synthesis, spectral, theoretical calculations and optical properties performance of substitutedazobenzene dyes Opt. Quant. Electron. 48178 